UDC 581.5

LBC E580.14

\title{
INFLUENCE OF INDUSTRIAL EMISSIONS ON MORPHOLOGICAL SIGNS OF LEAVES OF GREENING PLANTS
}

\author{
Tulkin U. Rakhimov
}

Karshi Engineering and Economics Institute, Karshi, Uzbekistan

Ikram Yusupov

Karshi Engineering and Economics Institute, Karshi, Uzbekistan

\section{Zafar R. Boirov}

Karshi Engineering and Economics Institute, Karshi, Uzbekistan

\begin{abstract}
Currently, studies of the industrial environment and related theoretical and applied environmental problems are undoubtedly relevant. Therefore, the indicators of environmental monitoring of greening tree species are the main indicators of the ecological situation in the industrial zones of the arid zone of the South of Uzbekistan. The article investigates the effect of $\mathrm{SO}_{2}$ on the morphometric index of leaf blades of some planted trees. Based on the information collected, a morphometric indicator of leaf blades and its relationship with the concentration of sulfur in the atmosphere are provided. Based on the changes in morphological and anatomical and some biological indicators, the degree of stability of greening species is revealed. The results obtained can be used in monitoring green spaces of industrial regions, as well as for predicting the effects of environmental pollution. The research results can serve as a scientific basis for the selection and regionalization of tree species for landscaping the industrial centers of the arid zone. According to our observations, changes in signs towards xeromorphy show a direct relationship with gas resistance, because these indicators depend on the structural features of the leaf blade. In particular, xeromorphic signs are the following: a decrease in the leaf blade, an increase in pubescence, an increase in the number of stomata per $\mathrm{mm}^{2}$, length of venation, etc. We recommend using ash for landscaping streets and parks in the arid zone. Due to the high decorative and drought-resistant properties, they should be used in group, linear, alley, as well as mixed plantings. Considering gas resistance, drought resistance, as well as salt tolerance of elm and quince, we recommend using them for landscaping industrial regions, as well as for planting shelterbelts. In large industrial centers, we recommend using maple, ash and elm for landscaping, as they have more resistant signs to toxicants, in particular to sulphurous anhydride. The analysis of the obtained research data allows stating that there is a relationship between the concentration of sulphurous anhydride and the morphometric indicators of leaf blades of greening trees in industrial zones.
\end{abstract}

Key words: leaves, emissions, response, morphology, resistance.

Citation. Rakhimov T.U., Yusupov I., Boirov Z.R. Influence of Industrial Emissions on Morphological Signs of Leaves of Greening Plants. Natural Systems and Resources, 2020, vol. 10, no. 2, pp. 26-32. (in Russian). DOI:

https://doi.org/10.15688/nsr.jvolsu.2020.2.3

УДК 581.5

ББК Е580.14

\section{ВЛИЯНИЕ ПРОМЫШЛЕННЫХ ВЫБРОСОВ НА МОРФОЛОГИЧЕСКИЕ ПРИЗНАКИ ЛИСТЬЕВ ОЗЕЛЕНЯЕМЫХ РАСТЕНИЙ}

\author{
Тулкин Уктамович Рахимов
}

Каршинский инженерно-экономический институт, г. Карши, Республика Узбекистан 


\section{Икрам Юсупов}

Каршинский инженерно-экономический институт, г. Карши, Республика Узбекистан

\section{Зафар Равшанович Боиров}

Каршинский инженерно-экономический институт, г. Карши, Республика Узбекистан

Аннотация. В настоящее время исследования промышленной среды и связанные с ними теоретические и прикладные экологические проблемы, несомненно, актуальны. Поэтому показатели экологического мониторинга озеленяемых древесных пород является основными показателями экологической обстановки промышленных зон аридной зоны Юга Узбекистана. В статье исследовано влияние $\mathrm{SO}_{2}$ на морфометрический показатель пластин листьев некоторых посаженных деревьев. Согласно собранной информации, предусматривается морфометрический показатель пластин листьев и его связь с концентрацией серы в атмосфере. На основании изменений морфолого-анатомических и некоторых биологических показателей выявлены степень устойчивости озеленяемых пород. Полученные результаты работы могут быть использованы в мониторинге зеленых насаждений промышленных регионов, а также для прогнозирования последствий загрязнения окружающей среды. Результаты исследований могут служить научной основой при подборе и районирования древесных пород для озеленения промышленных центров аридной зоны. Изменение признаков в сторону ксероморфности, по нашим наблюдениям, проявляет прямую взаимосвязь с газоустойчивостью, так как, эти показатели зависят от структурных особенностей листовой пластинки. В частности, ксероморфными являются такие признаки как: уменьшение листовой пластинки, увеличение опушения, возрастание числа устьиц на мм², длина жилкования и др. Для озеленения улиц и парков в условиях аридной зоны, рекомендуем использовать ясень. Благодаря высоким декоративным и засухоустойчивым свойствам их следует использовать в групповых, линейных, аллейных, а также смешанных посадках. Учитывая газоустойчивость, засухоустойчивость, а также солевыносливость вяза и айвы, рекомендуем использовать его для озеленения промышленных регионов, а также для полезащитных насаждений. В крупных промышленных центрах рекомендуем для озеленения использовать клен, ясень и вяз, так как они обладают более устойчивыми признаками к токсикантам, в особенности - к сернистому ангидриду. Анализируя полученные данные исследований, можно с уверенностью утверждать, что существует взаимосвязь между концентрацией сернистого ангидрида и морфометрическими показателями листовых пластинок озеленяемых древесных пород в условиях промышленных зон.

Ключевые слова: листья, выбросы, ответная реакция, морфология, устойчивость.

Цитирование. Рахимов Т. У., Юсупов И., Боиров 3. Р. Влияние промышленных выбросов на морфологические признаки листьев озеленяемых растений // Природные системы и ресурсы. - 2020. - Т. 10, № 2. C. 26-32. - DOI: https://doi.org/10.15688/nsr.jvolsu.2020.2.3

Введение. Интенсивное развитие промышленности и сельского хозяйства требует всестороннего учета загрязнения атмосферы, природных вод, почв, его влияния на растительный и животный мир, на здоровье и благосостояние человека, а также и прогнозной оценки влияния загрязнений на различные экосистемы и биосферу в целом. Эта проблема может быть успешно решена только совместными усилиями специалистов самых разных отраслей науки и техники.

В решении проблемы сохранения чистоты окружающей среды один из несомненных приоритетов принадлежит мониторингу древесных пород-озеленителей, которые являются основными биологическими фильтрами для крупных городов и промышленных центров. В Узбекистане для озеленения городов и промышленных объектов используются более 100 видов декоративных древесных и кустарниковых пород. На основе комплексных исследований их биологических признаков, включая морфолого-анатомические и физиологобиохимические, можно выявить степень устойчивости тех или иных видов к различным загрязнителям с целью использования в оптимизации экологической обстановки региона и снижения последствий антропогенной деятельности.

Биомониторинг является составной частью экологического мониторинга слежения за состоянием окружающей среды по морфометрическим показателям особенно растений. В задачи биомониторинга входит регулярно проводимая оценка качества окружающей среды с помощью широко распространенных 


\section{ЭкоЛОГИЯ И БИоЛОГИя}

в промышленных зонах эндемичных и аклиматизированных древесных пород по морфометрическим признакам.

В настоящее время исследования промышленной среды и связанные с ними теоретические и прикладные экологические проблемы, несомненно актуальны. В последние десятилетия наблюдается интенсивное насыщение атмосферы газообразными и пылевидными отходами промышленных предприятий [2]. Они вызывают ухудшение условий существования биоты, создавая угрозу здоровью населения, нарушению климата в локальных и глобальных масштабах [4]. В связи с этим остро ощущается потребность в научно-обоснованных и практических мероприятиях по предотвращению загрязнения атмосферы и сохранению оптимальных условий существованию биосферы в целом [3].

Если рассматривать фитоценоз загрязняющее вещество первоначально поступает в растение через устьица - отверстия, имеющееся на листьях, в нормальных условиях, использующихся для газообмена. Диоксид серы, прежде всего, воздействует на клетки, которые регулируют открывание этих отверстий. Степень их открывания и факторы, влияющие на нее, в начальный период являются основными параметрами, определяющими интенсивность воздействия загрязнителей. Даже при очень малых концентрациях диоксид серы способен оказывать стимулирующее действие, в результате которого при достаточно высокой относительной влажности устьица остаются постоянно открытыми. В то же время при высоких концентрациях диоксида углерода устьица закрываются. Кроме того, в случае высокой влажности устьица открываются, в случае низкой - закрываются.

Однако сера необходима для нормального роста растений, и присутствие $\mathrm{SO}_{2}$ может оказывать влияние и на усвояемость серы. Растения потребляют серу в восстановленном состоянии. В присутствии $\mathrm{SO}_{2}$ основным продуктом становится сульфат; присутствует также цистеин, глютатион, и, по меньшей мере, одно не идентифицированное вещество. Основными промежуточными соединениями при восстановлении сульфатов являются сульфиты.

Растения как продуценты экосистем в течение всей жизни, привязанные к локальной территории и подверженные влиянию двух сред - почвенной и воздушной, наиболее полно отражают весь комплекс воздействий на систему [6]. Наглядными морфометрическими показателями состояния древесных популяций являются: длина и ширина листовой пластинки, площадь листовой поверхности и удельная плотность листа, отражающие все многообразие действующих факторов. Морфометрические измерение листовых пластинок проводилось по стандартной методике А.Е. Васильева [2].

Анализ литературных данных показал вместе, что ранее практически не было изучено влияние промышленных выбросов на важнейшие биологические признаки таких пород деревьев как Acer negundo L. (клен ясенелистный), Fraxinus syriaca Boiss. (ясень сирийский) и Ulmus pumila L. (вяз приземистый), перспективных для озеленения промышленных зон в Узбекистане, в частности - в аридных условиях Кашкадарьинской области (на примере промышленных объектов).

Нами было проанализировано изменение этих показателей на примере плодовых Cydonia oblonga Mill. - Айва обыкновенная, и озеленяемых (Ulmus pumila L. - Вяз приземистый, Fraxinus syriaca Boiss. - Ясень сирийский разных по устойчивости древесных пород произрастающих на территории Мубарекского газоперерабатывающего завода (Опыт-1), Шуртаннефтгаз УДП (Опыт-2), Шуртанского газохимического комплекса (Опыт-3) под влиянием $\mathrm{SO}_{2}$ и относительно чистая санитарная зона города Карши (Контроль) [8]. Кроме того, нами была исследована агроклиматическая и производственная характеристика районов исследования (см. табл. 1). Основным загрязнителем окружающей среды исследуемых промышленных зон является сернистый ангидрид.

Уже давно исследователями замечено, что вблизи предприятий, выбрасываемых в атмосферу большое количество пылевидных частиц, линейные размеры ассимиляционных органов и прирост побегов растений меньше в 2-5 раз по сравнению с растениями вне зоны запыления [3].

Проведенные нами измерения длины сложного листа ясеня и простых листовых пластинок айвы и вяза показывают, что мак- 
симальная длина листовой пластинки отмечена у деревьев, произрастающих в контрольной зоне города Карши и в Опыт-3 ( в Карши вяз 6,2 мм; ясень - 4,7 мм; айва - 7,9 мм и в участках ШГХК вяз - 6,1 мм; ясень - 4,5 мм; айва 7,5мм), и разница между этими точками незначима (табл. 2). На этих же исследуемых районах нами выявлено самое минимальное содержание сернистого ангидрида в воздухе (табл. 1). Относительно близкие значения имеют показатели, полученные на Опыт-1 (вяз 5,8 мм; ясень - 4,4 мм; айва - 7,2 мм) и Опыт2 (вяз - 5,9 мм; ясень - 4,5 мм; айва - 7,5 мм).

Достоверная разница в изменении длины листа на этих объектах статистически относительно значимо отличается от условного контроля. И самая минимальная длина листовой пластинки была замечена в самых загрязненных районах исследования, на участке Опыт-1 (вяз - 5,8 см; ясень - 4,4 см; айва -
7,2 см) и Опыт-2 (вяз - 5,9 см; ясень - 4,5 см; айва $-7,5$ см), где установлено самое высокое содержание $\mathrm{SO}_{2}$. Эти значения статистически значимо различаются от всех остальных.

Аналогичная картина характерна и для признака - ширина листовой пластинки. Также нами установлено, что наиболее широкие листья на деревьях в контроле и в Опыт-3 (вяз - 4,3 см; ясень - 2,6 см; айва $-4,6$ см и соответственно вяз - 4,4 см; ясень - 2,4 см; айва - 4,1 см). А наименьший размер ширины листовой пластинки исследуемых пород снова отмечен на участке Опыт-1 (вяз - 4,1 см; ясень - 2,3 см; айва - 4,1 см) и Опыт-2 (вяз 4,1 см; ясень - 2,3 см; айва - 4,3 см). Двухфакторный дисперсионный анализ показал относительно статистически значимую разницу по ширине листа древесных пород между двумя последними опытными районами исследования и остальными районами.

Таблица 1

Краткая характеристика районов исследования, 2016 г.

\begin{tabular}{|l|c|c|c|c|c|}
\hline \multicolumn{1}{|c|}{ Районы исследования } & $\begin{array}{c}\text { Концентрация } \\
\mathrm{SO}_{2} \text { в атмо- } \\
\text { сфере, } \text { г }^{3}\end{array}$ & $\begin{array}{c}\text { Гумус, } \\
\text { мг/кг }\end{array}$ & $\begin{array}{c}\text { Средне- } \\
\text { годовая тем-ра } \\
\text { воздуха, }{ }^{\circ} \mathrm{C}\end{array}$ & $\begin{array}{c}\text { Осад- } \\
\text { ки, мм }\end{array}$ & $\begin{array}{c}\text { Вегетаци- } \\
\text { онный пе- } \\
\text { риод, дни }\end{array}$ \\
\hline Санитарная зона г. Карши & $0,005 \pm 0,0015$ & $0,9-1,6$ & 14,3 & 240 & 298 \\
\hline Опыт-1 (МГПЗ) & $0,043 \pm 0,018$ & $0,6-0,8$ & 14,9 & 165 & 283 \\
\hline Опыт-2 (Шуртаннефтгаз УДП) & $0,036 \pm 0,015$ & $0,9-1,1$ & 15,7 & 210 & 301 \\
\hline Опыт-3 Шуртан ГХК & $0,024 \pm 0,009$ & $0,8-1,3$ & 15,7 & 210 & 301 \\
\hline ПДК (для древесных видов) & 0,03 & $1,9-2,4$ & - & - & - \\
\hline
\end{tabular}

Таблииа 2

Средние значения морфометрических показателей исследуемых пород

\begin{tabular}{|c|c|c|c|c|c|}
\hline & Районы исследования & Контроль & Опыт-1 & Опыт-2 & Опыт-3 \\
\hline & Концентрация $\mathrm{SO}_{2}, \mathrm{мг} / \mathrm{M}^{3}$ & $0,005 \pm 0,0015$ & $0,043 \pm 0,018$ & $0,036 \pm 0,015$ & $0,024 \pm 0,009$ \\
\hline \multirow{6}{*}{$\stackrel{\tilde{E}}{\tilde{\omega}}$} & Прирост годичного побега,(см) & $53,4 \pm 1,92$ & $46,7 \pm 2,28$ & $48,1 \pm 2,45$ & $50,8 \pm 2,43$ \\
\hline & Длина листа, (см) & $6,2 \pm 0,71$ & $5,8 \pm 0,65$ & $5,9 \pm 0,89$ & $6,1 \pm 0,67$ \\
\hline & Ширина листа, (см) & $4,3 \pm 0,92$ & $4,1 \pm 0,71$ & $4,1 \pm 0,75$ & $4,2 \pm 0,086$ \\
\hline & Площадь лист. пл., $\left(\mathrm{cm}^{2}\right)$ & $26,6 \pm 1,23$ & $23,8 \pm 1,02$ & $24,8 \pm 0,94$ & $25,0 \pm 0,70$ \\
\hline & Уд. пов. плотн. листа, $\left(г \mathrm{p} / \mathrm{cm}^{2}\right)$ & $0,024 \pm 0,0011$ & $0,021 \pm 0,0018$ & $0,024 \pm 0,0010$ & $0,023 \pm 0,0009$ \\
\hline & Длина черешка, (см) & $2,1 \pm 0,044$ & $1,97 \pm 0,045$ & $2,08 \pm 0,05$ & $2,1 \pm 0,058$ \\
\hline \multirow{6}{*}{ } & Прирост годичного побега,(см) & $28,8 \pm 1,06$ & $25,7 \pm 0,97$ & $25,3 \pm 1,23$ & $25,9 \pm 1,52$ \\
\hline & Длина листа, (см) & $4,7 \pm 0,073$ & $4,4 \pm 0,061$ & $4,5 \pm 0,051$ & $4,5 \pm 0,086$ \\
\hline & Ширина листа, (см) & $2,6 \pm 0,061$ & $2,3 \pm 0,41$ & $2,3 \pm 0,39$ & $2,4 \pm 0,040$ \\
\hline & Площадь лист. пл., $\left(\mathrm{cm}^{2}\right)$ & $36,60 \pm 1,56$ & $30,36 \pm 1,42$ & $31,05 \pm 1,33$ & $32,4 \pm 1,06$ \\
\hline & 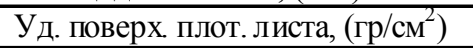 & $0,036 \pm 0,0012$ & $0,031 \pm 0,0011$ & $0,033 \pm 0,0022$ & $0,031 \pm 0,0031$ \\
\hline & Длина черешка, (см) & $5,6 \pm 0,11$ & $5,2 \pm 0,088$ & $5,3 \pm 0,11$ & $5,3 \pm 0,12$ \\
\hline \multirow{6}{*}{ 苞 } & Прирост годичного побега,(см) & $31,8 \pm 1,32$ & $28,6 \pm 1,01$ & $29,8 \pm 0,99$ & $29,7 \pm 1,13$ \\
\hline & Длина листа, (см) & $7,9 \pm 0,14$ & $7,2 \pm 0,072$ & $7,5 \pm 0,18$ & $7,5 \pm 0,20$ \\
\hline & Ширина листа, (см) & $4,6 \pm 0,071$ & $4,1 \pm 0,065$ & $4,3 \pm 0,051$ & $4,4 \pm 0,061$ \\
\hline & Площадь лист. пл., $\left(\mathrm{cm}^{2}\right)$ & $36,34 \pm 1,28$ & $29,52 \pm 1,32$ & $32,25 \pm 0,93$ & $30,75 \pm 0,64$ \\
\hline & 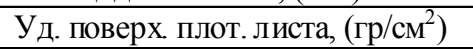 & $0,019 \pm 0,0054$ & $0,017 \pm 0,0052$ & $0,017 \pm 0,0024$ & $0,017 \pm 0,0021$ \\
\hline & Длина черешка, (см) & $2,1 \pm 0,051$ & $1,9 \pm 0,022$ & $2,09 \pm 0,037$ & $1,9 \pm 0,041$ \\
\hline
\end{tabular}




\section{ЭкоЛОГИЯ И БИоЛОГИя}

Таким образом, данные двухфакторного дисперсионного анализа показывают статистически значимое влияние района исследования на длину и ширину листовой пластинки исследуемых пород.

Также нами установлена обратная корреляционная зависимость между содержанием сернистого ангидрида в атмосферном воздухе и изменением параметров длины $(\mathrm{r}=-0,85)$ и ширины $(\mathrm{r}=-0,79)$ листа у вяза, длины $(\mathrm{r}=-0,89)$ и ширины $(\mathrm{r}=-0,84)$ листа у ясеня и длины $(\mathrm{r}=-0,87)$ и ширины $(\mathrm{r}=-0,82)$ листа у айвы. Кроме того, мы видим, что эти признаки коррелируют между собой $(\mathrm{r}=0,90)$.

По литературным данным известно, что площадь листовой поверхности и удельная поверхностная плотность листа (УППЛ) являются диагностическими признаками устойчивости древесных растений в условиях городской среды [1]. Интенсивность фотосинтеза зависит от площади листовой пластинки, которая влияет и на продуктивность $[9 ; 10 ; 11]$. Косвенным показателем продуктивности является УППЛ.

При изучении такого морфометрического показателя, как площадь листовой пластинки нами получены следующие результаты: наименьшее значение площади листа характерно для участков Опыт-1 (вяз - 23,8 cм²; ясень $-30,36 \mathrm{~cm}^{2}$; айва $\left.-29,52 \mathrm{~cm}^{2}\right)$, где и обнаружено относительно высокое содержание диоксида серы, затем по возрастанию площади и уменьшению содержания $\mathrm{SO}_{2}$ в воздухе идут участок Опыт-2 (вяз - 24,8 $\mathrm{cm}^{2}$; ясень $31,05 \mathrm{~cm}^{2}$; айва $-30,75 \mathrm{~cm}^{2}$ ) и Опыт-3 (вяз $25,0 \mathrm{~cm}^{2}$; ясень - 32,4 см${ }^{2}$; айва $\left.-30,75 \mathrm{~cm}^{2}\right)$ с почти одинаковыми результатами и контрольный участок с наибольшей площадью листовой пластинки и наименьшим количеством сернистого ангидрида в воздухе.

Существуют сведения, что удельная поверхностная плотность листа связывает процессы роста и фотосинтеза, так как отражает накопление сухого вещества единицей поверхности. Чем выше УППЛ, тем эффективнее идут процессы фотосинтеза, так как в расчете на единицу поверхности листа синтезируется большая биомасса [5; 7].

Наши исследования по измерению УППЛ показали, что с увеличением содержания сернистого ангидрида и пыли в возду- хе увеличивается плотность листа. Так, на контрольных участках и Опыт-3 отмечены относительно максимальные значения УППЛ, которые составили соответственно у вяза -

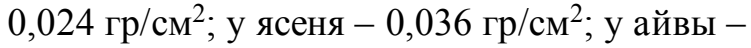

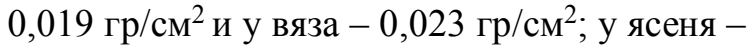
$0,031 г \mathrm{rp} / \mathrm{cm}^{2} ;$ у айвы $-0,017 г \mathrm{p} / \mathrm{cm}^{2}$ соответственно, тогда как в Опыте-1 всего у вяза $0,021 г \mathrm{rp} / \mathrm{cm}^{2} ;$ у ясеня $-0,031 г \mathrm{rp} / \mathrm{cm}^{2} ;$ у айвы -

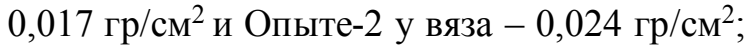
у ясеня $-0,033$ гр/см${ }^{2} ;$ у айвы $-0,017 г р / \mathrm{cm}^{2}$. Кроме того, именно на Опыт-1 и Опыт-2 нами обнаружено самое высокое содержание $\mathrm{SO}_{2}$ и пыли. Также мы видим, что на контрольных участках плотность листа составила у вяза -

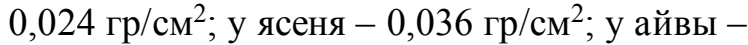
0,019 гр/см ${ }^{2}$, что примерно в $1,15-1,2$ раза больше чем в Опыте-1. Двухфакторный дисперсионный анализ показал достоверную разницу в изменении удельной поверхностной плотности листа и влияния районов исследования $(\mathrm{P}<0,10)$. Проведя корреляционный анализ данного признака, мы определили, что существует обратная зависимость между УППЛ листовой пластинки и содержанием диоксида серы в воздухе. $(\mathrm{r}=-0,79)$. При построении графика зависимости взят десятичный логарифм УППЛ листовой поверхности.

Заключение. На основании изменений морфолого-анатомических и некоторых биологических показателей выявлены степень устойчивости озеленяемых пород. Полученные результаты работы могут быть использованы в мониторинге зеленых насаждений промышленных регионов, а также для прогнозирования последствий загрязнения окружающей среды. Результаты исследований могут служить научной основой при подборе и районирования древесных пород для озеленения промышленных центров аридной зоны.

Изменение признаков в сторону ксероморфности, по нашим наблюдениям, проявляет прямую взаимосвязь с газоустойчивостью, так как, эти показатели зависят от структурных особенностей листовой пластинки. В частности, ксероморфными являются такие признаки как: уменьшение листовой пластинки, увеличение опушения, возрастание числа устьиц на мм² ${ }^{2}$ длина жилкования и др.

Для озеленения улиц и парков в условиях аридной зоны рекомендуем использовать 
ясень. Благодаря высоким декоративным и засухоустойчивым свойствам их следует использовать в групповых, линейных, аллейных, а также смешанных посадках. Учитывая газоустойчивость, засухоустойчивость, а также солевыносливость вяза и айвы, рекомендуем использовать его для озеленения промышленных регионов, а также для полезащитных насаждений.

Рекомендуем смешанные посадки с сосной эльдарской и сафорой японской, клена ясенелистного и ясеня сирийского, так как. они обладают относительно высокими фитонцидными, пылезадерживающими свойствами, а также соответствующей устойчивостью к промышленным выбросам. Такая комбинация насаждений способствует очистке воздуха от патогенных микроорганизмов, пыли и токсикантов. Использование этих пород мы рекомендуем для озеленения лечебных и рекреационных пансионатов, школ и детских садов.

В крупных промышленных центрах рекомендуем для озеленения использовать клен, ясень и вяз, так как они обладают более устойчивыми признаками к токсикантам, в особенности - к сернистому ангидриду.

\section{СПИСОК ЛИТЕРАТУРЫ}

1. Васильев, А. Е. Ботаника, Морфология и анатомия растений / А. Е. Васильев. - М. : Наука, 1988. $-327 \mathrm{c}$.

2. Воскресенская, О. Л. Организм и среда: факториальная экология / О. Л. Воскресенская, Е. А. Скочилова. - Йошкар-Ола : МарГУ, 2005. - 175 с.

3. Илькун, Г. М. Отфильтровывание воздуха от поллютантов древесными растениями / Г. М. Илькун. - Таллин : [б. и.], 1982. - 138 с.

4. Калверт, С. Защита атмосферы от промышленных загрязнений / С. Калверт, Г. Инглунд. - М. : Металлургия, 1988. - 286 с.

5. Кузьмин, А. В. Этология многоуровневых систем устойчивости интродуцированных и аутохтонных древесных растений / А. В. Кузьмин. - Апатиты : КНЦРАН, 2001. -251 c.

6. Рунова, Е. М. Экологический мониторинг лесных биоценозов в зонах промышленных выбросов / Е. М. Рунова // Природные и интеллектуальные ресурсы Сибири. - Томск : ТГУ, 2004. - С. 132-135.

7. Чекрыгин, В. В. Особенности регулирования светового режима в насаждениях яблони Западного Предкавказья : автореф. ... канд. биол. наук
/ Чекрыгин Валентин Васильевич. - Краснодар, 2005. $25 \mathrm{c}$.

8. Чичев, А. В. Практикум по анатомии и морфологии растений / А. В. Чичев, И. И. Андреева, Л. С. Родман. - М. : Колос, 2005. - 159 с.

9. Ahmad, M. Seeing the World in Red and Blue: Insight Info Plant Vision and Photoreceptors / M. Ahmad // Current Opinion in Plant Biology. 1999. - Vol. 2. - P. 230-235.

10. Briggs, W. R. Blue-Light Photoreceptors in Higher Plants / W. R. Briggs, E. Huala // Annu. Rev. Cell Dev. Biol. - 1999. - Vol. 15. - P. 33-62. - DOI: https://doi.org/10.1146/annurev.cellbio.15.1.33.

11. Lin, C. Plant Blue-Light Receptors / C. Lin // Trends in Plant Science. - 2000. - Vol. 5, № 8. P. 337-342.

\section{REFERENCES}

1. Vasiliev A.E. Botanika, Morfologiya $i$ anatomiya rasteniy [Botany, Morphology, and Anatomy of Plants]. Moscow, Science Publ., 1988. 327 p.

2. Voskresenskaya O.L., Skochilova E.A. Organizm i sreda: faktorialnaya ekologiya [Organism and the Environment: Factorial Ecology]. Yoshkar-Ola, MarGU Publ., 2005. 175 p.

3. Ilkun G.M. Otfiltrovyvanie vozdukha ot pollyutantov drevesnymi rasteniyami [Filtering Air from Pollutants by Woody Plants]. Tallinn, 1982. $138 \mathrm{p}$.

4. Calvert C., Inglund G. Zashchita atmosfery ot promyshlennykh zagryazneniy [Protection of the Atmosphere from Industrial Pollution]. Moscow, Metallurgy, 1988. 286 p.

5. Kuzmin A.V. Etologiya mnogourovnevykh sistem ustoichivosti introdutsirovannykh $i$ autokhtonnykh drevesnykh rasteniy [Ethology of Multilevel Resistance Systems of Introduced and Autochthonous Woody Plants]. Apatity, KSC RAS, 2001. 251 p.

6. Runova E.M. Ekologicheskiy monitoring lesnykh biotsenozov $\mathrm{v}$ zonakh promyshlennykh vybrosov [Ecological Monitoring of Forest Biocenoses in Zones of Industrial Emissions]. Prirodnyye i intellektualnyye resursy Sibiri [Natural and Intellectual Resources of Siberia]. Tomsk: TSU, 2004, pp. 132-135.

7. Chekrygin V.V. Osobennosti regulirovaniya svetovogo rezhima $v$ nasazhdeniyakh yabloni Zapadnogo Predkavkazia: avtoref. diss. ... kand. biol. nauk [Features of Regulation of the Light Regime in Apple Plantations of the Western Ciscaucasia. Cand. biol. sci. abs. diss.]. Krasnodar, 2005. 25 p.

8. Chichev A.V., Andreeva I.I., Rodman L.S. Praktikum po anatomii $i$ morfologii rasteniy 


\section{ЭкоЛОГия и БИоЛОГИя}

[Workshop on the Anatomy and Morphology of Plants]. Moscow, Kolos, 2005. 159 p.

9. Ahmad M. Seeing the World in Red and Blue: Insight Info Plant Vision and Photoreceptors. Current Opinion in Plant Biology, 1999, vol. 2, pp. 230-235.
10. Briggs W. R., Huala E. Blue-Light Photoreceptors in Higher Plants. Annu. Rev. Cell Dev. Biol, 1999, vol. 15, pp. 33-62. DOI: https://doi.org/ 10.1146/annurev.cellbio.15.1.33.

11. Lin C. Plant Blue-Light Receptors. Trends in Plant Science, 2000, vol. 5, no. 8, pp. 337-342.

\section{Information About the Authors}

Tulkin U. Rakhimov, Candidate of Sciences (Biology), Department of Environmental Protection and Ecology, Karshi Engineering and Economic Institute, Prosp. Mustakillik, 225, 180004 Karshi, Uzbekistan, burch-ecolog@mail.ru.

Ikram Yusupov, Lecturer, Department of Environmental Protection and Ecology, Karshi Engineering and Economic Institute, Prosp. Mustakillik, 225, 180004 Karshi, Uzbekistan, yusupov.i@mail.ru.

Zafar R. Boirov, Assistant Lecturer, Department of Environmental Protection and Ecology, Karshi Engineering and Economic Institute, Prosp. Mustakillik, 225, 180004 Karshi, Uzbekistan, boyirov.zafar@mail.ru.

\section{Информация об авторах}

Тулкин Уктамович Рахимов, кандидат биологических наук, доцент кафедры «Защита окружающей среды и экология», Каршинский инженерно-экономический институт, просп. Мустакиллик, 225, 180004 г. Карши, Узбекистан, burch-ecolog@mail.ru.

Икрам Юсупов, преподаватель кафедры «Защита окружающей среды и экология», Каршинский инженерно-экономический институт, просп. Мустакиллик, 225, 180004 г. Карши, Узбекистан, уusupov.i@mail.ru.

Зафар Равшанович Боиров, ассистент кафедры «Защита окружающей среды и экология», Каршинский инженерно-экономический институт, просп. Мустакиллик, 225, 180004 г. Карши, Узбекистан, boyrov.zafar@mail.ru. 